Prace Polonistyczne, seria LXXII, 2017

ISSN: 0079-4791; e-ISSN: 2450-9353

DOI: $10.26485 / \mathrm{PP} / 2017 / 72 / 2$

Magdalena Lubelska-Renouf

\title{
AKULTURACJA? CZY INNY WEKTOR WSPÓŁCZESNOŚCI? KILKA SŁÓW O REFLEKSJI CZESŁAWA MIŁOSZA
}

\section{SŁOWA KLUCZOWE}

Miłosz Czesław; Cheng Françoi; Scheler Max; Cézanne; akulturacja; malarstwo chińskie; polska poezja; haiku

Załóżmy, że każda epoka ma własny Weltanschauung.

Załóżmy, że ten dzisiejszy wchłonął prawie wszystkie różnice kulturowe w strefie tak zwanego okcyndentalizmu i stał się kulturą dominującą niezależnie od historii i geografii. Że pozorny katolicyzm rdzennego Polaka prawie niczym nie różni się od pozornego islamizmu francuskiego Tunezyjczyka, a pozorny ateizm berkelejskiego intelektualisty od pozornego neopogaństwa internetowego nastolatka. Jednym słowem, że Max Scheler miał rację, mówiąc o „zacieraniu się przeciwieństw" (Scheler 1993: 67).

Załóżmy, że niektóre wybitne jednostki, bo już nie kultury, próbują popłynąć pod główny kulturalny prąd rzeki Weltanschauung. Czy jedyne, co je czeka to mielizna? Czyli, jak niedawno mówiono w nieco innym żargonie innego paradygmatu, śmietnik historii?

Inaczej mówiąc, załóżmy, że Max Scheler nie miał racji i że te potencjalne zbuntowane jednostki mają inny wybór niż ten między proponowanym albo: albo. Albo akulturacja (uzgodnienie własnych skłonności intelektualnych z kulturą dominująca) — albo mielizna, mierność i nicość.

Magdalena Lubelska-Renouf — dr, Professeur agrégé (PRAG), UFR de polonais, Sorbonne Paris 4, Centre universitaire Malesherbes, 108 bd Malesherbes, 75017 PARIS, FRANCE; e-mail: magdarenouf@gmail.com 
Załóżmy na koniec, że wiemy, czym jest dominujący współczesny Weltanschauung.

Ci, którzy weń wierzą, zgadzają się co do faktu, że każda epoka ma własne oryginalne doświadczenie, własny fundamentalny problem, który próbuje po swojemu rozwiązać i który ją definiuje i odróżnia.

Gorzej jest ze znalezieniem wspólnego mianownika.

Nie mając zamiaru przekształcić naszego artykułu w naukową, lub pseudo, inwentaryzację, powiedzmy sobie, że powszechnie stosowany dzisiaj termin najlepiej określa badane zjawisko. Będziemy więc z jednej strony, mówić o globalizacji; z drugiej strony, tej Czesława Miłosza, znajdziemy inną propozycję. Bo właśnie ten poeta będzie w naszym ujęciu jednostką, która próbowała płynąć pod prąd kultury, wybierając, czy stwarzając, inne wektory współczesności.

Miłosz nazwał naszą epokę neomanicheizmem i, po żmudnym odtworzeniu jego intencji, możemy dorzucić co najmniej dwa epitety do tego określenia: nihilistyczny i niemetafizyczny — oba ukryte w „neo” (Miłosz 1995: 21).

Zastąpmy metaforę naszej pierwszej roboczej hipotezy, płynięcia pod prąd, konkretnym stwierdzeniem: poezja Miłosza starała się umetafizycznić i odnicestwić nasz współczesny, dominujący, globalny nie-zawsze-świadomy, kulturalny-lub-nie, pan-neomanicheizm. Co nie oznacza, że powróciła do manicheizmu klasycznego - bo taki nigdy chyba nie istniał.

Jeżeli Miłoszowi udała się ta sztuka, a jest to nasza druga robocza hipoteza, to to poetyckie zwycięstwo byłoby naszą trzecią hipotezą, a mianowicie, że można wytyczyć inne wektory akulturacji, inne od tych, które znajdujemy u Maxa Schelera.

W pewnym sensie przynajmniej, ale $\mathrm{w}$ sensie natychmiast rozpoznawalnym jako sens ${ }^{1}$ — znaczenie i kierunek — Max Scheler miał rację. To, co on odgadywał jako nadchodzącą nowość, mówiąc o akulturacji i zacieraniu się przeciwieństw, jest naszą banalną codziennością. „Globalizacja” najbardziej rozpowszechniona dziś nazwa akulturacji, która dotarła wreszcie do kresu swoich możliwości, stając się jednym, wspólnym zbiorem czy zbiornikiem planetarnej kultury, jest na ustach wszystkich. To slogan, hasło, otwierające drzwi teraźniejszości i przyszłości:

Wszyscy [...] uważają „globalizację” za nieunikniony los świata, a także za nieodwracalny proces, kóry dotyczy każdego z nas w takim samym stopniu i w ten sam sposób (Bauman 2000: 5).

1 Sens: (XIe siècle): z łaciny (1) sensus (zmysł i znaczenie); (XIIe siècle) (2): z języków germańskich (kierunek, droga). 
Żadnej więc już dyskusji na temat spełnionej przepowiedni: jeżeli wszystkie nasze doświadczenia zyskują dzięki niej przejrzyste wyjaśnienie, jeżeli „Jesteśmy "globalizowani» a bycie "globalizowanym» znaczy to samo dla wszystkich, których ten proces dotyka" (Bauman 2000: 5), to w zasadzie możemy stwierdzić, że ten stan kultury stał się naszym nowym — naturalnym — środowiskiem i jedyne, co można w tej sytuacji zrobić, to dostosować się.

Akulturacja okazałaby się na koniec — naturalizacją. Ale właśnie w tym momencie ukazują się furtki zaznaczające możliwość wyjścia i pojawiają się głosy sprzeciwu tych, którzy próbują je otworzyć.

Jeden z nich należał do Czesława Miłosza.

Miłosz często porównywał swoją sytuację do kogoś, kto został zamknięty w ciemnym pokoju i ręką, na oślep, dotyka ścian, próbując odnaleźć ukryte drzwi (Miłosz 1997: 131).

Spróbujmy odtworzyć tok tych poszukiwań, zaczynając od ewidencji: poeta był $\mathrm{w}$ pełni świadomy analizowanego zjawiska, więcej, sytuacja globalizacji, rozpoznana jako intelektualnie jałowa i egzystencjalnie nie do zniesienia, była ważnym, może podstawowym, elementem jego dzieła, przesłanką i punktem wyjścia:

I oto ludzkość — jedna, zjednoczona kulturą filmu, telewizji, kaset, globalna wioska, w której na kontynentach i wyspach miliony białych, żółtych, brunatnych widzą to samo i zachowują się tak samo. [...] Jedna i niepodzielna cywilizacja nie jest nieszkodliwa. Jej inne imię jest bezosobowe, zbrutalizowane. Szlachetni filozofowie i teologowie ubolewający nad redukcją istoty ludzkiej do statusu zwierzęcia (żebyż to!) podobni są do ekologów bezsilnie przyglądających się, jak maszyny zwalają las dziewiczy w dorzeczu Amazonki. Gdyż dobre intencje niewiele mogą tam, gdzie ich przeciwnikiem nie jest żadna ideologia, żaden program, ale samorozmnażające się Nic. (Miłosz 1997: 22)

Miłosz jednak rzadko używa dominujących terminów, takich właśnie jak "globalizacja” czy „uniformizacja”, chociaż to on spolonizował amerykańskie pojęcia, leżące u podstaw tych zjawisk, wprowadzając do polszczyzny słowa, które zrobiły w niej zawrotną karierę - masowe środki przekazu i kultura masowa.

Fakt, że w swojej refleksji Miłosz unika pewnej terminologii jest faktem znaczącym: przemilczanie jednych i szukanie innych określeń świadczy już o próbie zmiany kierunku, próbie poszukiwania wyjścia z sytuacji, zdawałoby się, bez wyjścia. Miłosz używa więc innych nazw i najczęściej występujące, to przywołany już wcześniej „neomanicheizm” oraz „czarnowidztwo”. Czyli, w samym akcie nazywania fenomenu, podejmuje próbę jego waloryzacji (lub raczej dewaloryzacji) i zróżnicowania. Globalizacja, uniformizacja — te terminy są jak 
naturalne bloki granitu — jednolite, nieprzezroczyste i twarde; neomanicheizm natomiast jest już pewnym przekrojem, rzutem oka w głąb zjawiska — pozwala dojrzeć geologiczne warstwy, które je konstytuują, zrozumieć przyczyny i skutki.

Nadanie nowej nazwy, zrozumienie i przewartościowanie istniejących wektorów to pierwsze etapy zmiany sensu, sensu pojętego jako znaczenie i kierunek.

Zweryfikujmy tę terminologię: czarnowidztwo i neomanicheizm mają wspólny metaforyczny rdzeń: czerń. Manicheizm, w swojej esencji czarno-biały, $\mathrm{w}$ opisie materii przeciwstawionej niematerialnemu światłu (czyli transcendencji), jest całkowicie czarny: „świat w złu leży” (Jn 15, 18-19). Odczytując intencje Miłosza możemy więc uznać te terminy za mniej więcej jednoznaczne; odtąd będziemy mówić tylko o neomanicheizmie.

Czym jest dla nas manicheizm i dlaczego stał się, według Miłosza, wyznacznikiem naszej uniformizującej globalizacji?

Klasyczna definicja manicheizmu: „świat w złu leży” jest wciąż aktualna, ale nie potrzebujemy już dzisiaj dodatkowej wiedzy o tronach, potęgach, eonach, wpływach zoroastryzmu a nawet o trzonie manicheizmu, czyli o dualizmie. W neomanicheizmie dualizm, zasadnicze przeciwstawienie dobra i zła, światła i ciemności, ducha i materii, został nie tyle wyeliminowany, co przestawiony na inny tor. Powiedzmy, że z toru transcendencji został przestawiony na tor immanencji. Powiedzieliśmy wcześniej, że w przedrostku „neo” Miłosz zawarł dwie treści: nihilizm i negację metafizyki — możemy zradykalizować tę wizję i mówić po prostu o odrzuceniu transcendencji. Po której zostało Nic:

Prorok, jak sam to nazywał, nihilizmu europejskiego, Fryderyk Nietzsche, z dumą powiadał: „My nihiliści” i określał, co będzie „najskrajniejszą formą nihilizmu”. Będzie to „pogląd, zgodnie z którym wszelka wiara, wszelkie przekonanie, że coś jest zgodne z prawdą, będą z konieczności fałszywe dlatego po prostu, że nie ma prawdziwego świata. (Miłosz 1997: 42)

Dziwaczne koleje historii przekształciły arystokratyczny nihilizm Nietzschego najpierw w populistyczny nazizm, którego skutki, dobrze znane, doprowadziły $\mathrm{z}$ kolei do powstania równie populistycznej wersji neomanicheizmu:

Nie byłby chyba zadowolony, do czego w ciągu stu lat służyło jego dzieło. A bezgraniczna odwaga obrazoburcy, którą tak się szczycił? Cóż po niej dzisiaj, kiedy trzeba odwagi, żeby twierdzić coś przeciwnego? (Miłosz 1997: 43)

Mamy tutaj, według Miłosza, jedno z najbardziej obłędnych kół zatoczonych przez naszą kulturę i historię: transcendencja (i jej pochodne: prawda, Bóg, natura człowieka) zostaje odrzucona w imię nihilizmu, który przynosi wolność, to odrzucenie doprowadza do ludobójstwa, ludobójstwo prowokuje traumę, która 
z kolei prowadzi do oskarżenia transcendencji a następnie z powrotem do nihilizmu pojętego jako zabezpieczenie i przed transcendencją, i przed wolnością².

Definicja neomanicheizmu brzmiałaby więc mniej więcej tak: „system niereligijny, dominujący w świecie począwszy od XX wieku. Był reakcją na wydarzenia historyczne, które zostały odczytane jako katastrofa, po której nastąpiła śmierć Boga. Może zostać ujęty w stwierdzeniu: «świat w złu leży i nie ma prawdziwego świata»".

W naszej pół-żartobliwej parafrazie Wikipedii, która jednak dość wiernie odtwarza koncepcję Miłosza, odnajdujemy pewien specyficzny rys myślenia o kulturze: kiedy stwierdzamy, że „neomanicheizm był reakcją na”, to definiujemy fenomen kultury jako fenomen organiczny. I wtedy, kiedy w mówieniu o kulturze stosujemy metaforę choroby, możemy ją wzbogadzić o nowy element: leczenia.

Wystarczy dość pobieżny rzut oka na współczesne opisy kultury, żeby zauważyć pewną stałą: jest nią właśnie specyficzna metaforyka choroby. Zdanie „chorobą naszych czasów jest...” (Sosnowski 2015: 244)33 pojawia się regularnie w esejach nauk humanistycznych. Tradycja ta ma długi rodowód: kiedy obserwujemy, jak niektóre znaki (wartości, dzieła, symbole, obyczaje) zostają przez daną kulturę przyswojone, inne zaś z niej wyeliminowane, trudno nie skojarzyć tego zjawiska z systemem immunologicznym działającym wewnątrz organizmu.

Jest to szczególnie widoczne w terminie ukutym przez Miłosza, gdzie przedrostek „neo” wyznacza elementy odrzucone i sugeruje alergię, a człon — „manicheizm" - zawiera substancje pożądane i przepuszczane przez organizm. Alergia, ten skuteczny mechanizm obronny byłaby w naszej metaforze, wynikiem urazu — reakcją na kataklizmy XX wieku.

Pamiętamy, że zawarte $\mathrm{w}$ „neo” elementy: nihilizm (nihil = nic) i negacja metafizyki (czyli tego, co „jest” poza fizyka), sprowadziliśmy do wspólnego mianownika - odrzucenia transcendencji. Lub mówiąc prościej — religii:

Cywilizacja, w której tkwię, zaprzecza religii [...]. Każdy mój dzień z jego mnóstwem postrzeżeń ćwiczy mnie w antyreligii i nie mogę przypisać żadnym zrozumiałym dla mnie intencjom olbrzymich neonowych napisów głoszących: „Jezus ratuje od grzechu". (Miłosz 1995: 73)

Według diagnozy, którą postawiono kulturze w dwudziestym wieku, transcendencja byłaby tą substancją, która doprowadziła kulturalny organizm do katastrofy i przed którą broni się on dzisiaj za pomocą alergii. Główne, alergo-

2 Ten sam typ błędnego koła opisany został, profetycznie, przez Dostojewskiego w Braciach Karamazow jako „sziglajewszyzna”.

3 Przytaczam tu uwagi Jerzego Sosnowskiego na ten temat, bo w porządku chronologicznym są one najnowsze. 
genne, „składniki” transcendencji w wersji Miłosza to przede wszystkim pojęcie prawdy, typu metafizycznego, czyli prawdy o człowieku, Bogu i świecie, wspólnie konstytuujące tak zwaną rzeczywistość. Jej charakterystyką jest ruch w osi pionowej — podział na górę i dół; jej elementy pochodne to autorytet i hierarchia.

Te właśnie substancje, rozpoznane „wczoraj” jako ludobójcze, a „dzisiaj” jako alergogenne, zostały starannie wyeliminowane z naszej globalnej, chudej diety:

Są tacy, którzy wolą Nic niż religię z jej politycznym złem. Bo doświadczenie wykazuje, że człowiek owija się w podniosłość, czystość i szlachetność wysokiej sfery ducha, żeby udawać, że nie wie, co robią jego ręce. Tylko gdyby katolicyzm był wolny od takiej podwójności, miałby prawo wytknąć prawosławiu zbrodnie Karadżicza. (Miłosz 1997: 41)

Zauważmy, że eliminacja („wybór Nic”) jest tylko jednym ze sposobów neutralizacji szkodliwych dla organizmu substancji. Miłosz wspomina o innej możliwości, o neutralizacji przez deformację: Religia może zostać zdeformowana i wyeliminowana przez „rozmiękczenie” i wtedy rezultatem jest tak zwana „papka New Age", w której miesza się buddyzm w plastikowym opakowaniu, chrześcijaństwo i inne elementy pseudo religijne (Miłosz 1995: 251); albo, na odwrót przez „stwardnienie” — czyli wszelkiego rodzaju religijne integryzmy.

A jednak, Miłosz, dobrze wiedząc, że cieniem religii (Prawdy, Boga i świata) jest polityczne zło, w całym swoim dziele przeprowadza kontestację tego rozpoznania, udowadniając szkodliwość nihilizmu, który zlikwidował transcendencję. Szkodliwość ta według Miłosza może być subiektywna:

Rechoczącym cynikom, wbijającym ludziom w głowy, że nie ma dobra ni zła, że życie jest kłębowiskiem gryzących się szczurów, nie można powiedzieć: „skazujecie siebie na męki wieczne", bo śmieją się z wiary w życie po śmierci. Można jednak powiedzieć: „skazujecie siebie na wygraną, i to będzie dla was dostateczną karą”. (Miłosz 1997: 43)

Szkodliwość ta może prowadzić również do obiektywnego zagrożenia:

Czy Nic, święta dziura w umysłach zachodniej Europy, nie będzie pokusą dla islamskiego fundamentalizmu, który w imię Boga występuje już nie przeciwko niewiernym, ale ludziom pozbawionym jakiejkolwiek wiary? (Miłosz 1997: 44)

Miłosz otwarcie (i do końca) broni odrzuconych pojęć: prawdy, metafizyki (teologii) oraz absolutnego punktu odniesienia (Boga):

Dlaczego teologia? Bo pierwsze ma być pierwsze.

A tym jest pojęcie prawdy. I właśnie poezja swoim zachowaniem przerażonego ptaka tłukącego się o przezroczystą szybę, poświadcza, 
że nie umiemy żyć w fantasmagorii.

Oby do naszej mowy wróciła rzeczywistość.

To znaczy sens, niemożliwy bez absolutnego punktu odniesienia.

(Miłosz 2002: 63)

Być może podłożem tych poszukiwań innej rzeczywistości i innego rozpoznania choroby kultury, bardziej niż zagrożenie subiektywnym cynizmem i obiektywnym terroryzmem, jest jego własna alergia na nihilizm, do której często się przyznaje:

W starości, znalazłszy się w tropikalnym kraju, już wiedziałem, że zawsze szukałem lekarstwa na tę ohydę, która tym trwa, że nic nie znaczy. Nadać sens, jakikolwiek, byle nie ta krowia, doskonale obojętna rzeczywistość, bez celów, dążeń, afirmacji, negacji, niby ucieleśniona nicość. Religie! Ideologie! Pragnienia! Nienawiści! Przybywajcie, żeby zakryć waszą wzorzystą tkaniną to ślepe, które nawet nie ma nazwy. (Miłosz 1997: 67)

Nie wnikając w intencje, zadowólmy się opisem strategii.

Podkreślmy raz jeszcze: Miłosz, bardzo dobrze wiedząc, że cieniem transcendencji (prawdy, Boga i świata) jest polityczne zło, nie zgadza się z wnioskami nihilizmu i próbuje, w całym swoim dziele, postawić inną diagnozę. Wytyczyć nowe wektory sensu.

Sprawa jest skomplikowana, gdyż tych wektorów czy linii ścieżek, które prowadzą poza obszar neomanicheizmu, jest w dziele Miłosza wiele. W ramach tego artykułu możemy wykroić jedynie bardzo wąski skrawek refleksji, starając się wybrać fragment, który wydaje się nam najbogatszy, z nadzieją, że krzyżują się w nim wszystkie pozostałe linie.

Substancją szkodliwą czy wręcz zabójczą w diagnozie Miłosza jest kartezjański dualizm i Miłosz podejmuje systematyczną krytykę tego nurtu, który napotkał w naszej zachodniej kulturze warunki wybitnie sprzyjające, rozwijając się w patologiczny sposób i doprowadzając do zwyrodnienia transcendencji ${ }^{4}$. To on byłby główną, chociaż nie jedyną, przyczyną podwójnej katastrofy.

Pierwsza katastrofa została już opisana jako totalitarna i ludobójcza próba narzucenia całemu światu religijnych (czy pochodnych od religii) koncepcji prawdy, człowieka, świata i Boga. W jej opisie poeta zasadniczo zgadza się ze

4 Nietzsche odrzucałby więc tę właśnie zwyrodniałą formę transcendencji, co w pewnym sensie, w oczach Miłosza, jest usprawiedliwione. 
zwolennikami neomanicheizmu, lecz przyczyn tego stanu rzeczy szuka głębiej niż oni. Dla neomanichejczyków główna przyczyna katastrofy to jak najszerzej pojęta transcendencja. Według Miłosza jest to ujęcie zbyt płytkie, nie sięgające dostatecznie w głąb geologicznych warstw naszej historii. Bowiem religijne koncepcje prawdy, człowieka, świata i Boga uległy dość wcześnie poważnym schorzeniom, z których najpoważniejszym jest właśnie koncepcja kartezjańskiego dualizmu, czyli, ujmując to jak najszerzej, podział na ciało i ducha, materię i duchowość i, przede wszystkim, na podmiot i przedmiot. Drugą zaś katastrofą byłaby w wizji Miłosza sama błędna diagnoza i jej pochodna tzn. neomanicheizm. A także niewłaściwe lekarstwa aplikowane pacjentowi rzekomo choremu na transcendencję — subiektywizacja (Freud, Lacan i większość współczesnej literatury, która podważa rzeczywistość świata, przesuwając akcent na subiektywną percepcję, twierdząc, „że niby oprócz tych percepcji nic nie ma” — Miłosz 1995: 246), a także wymienione już: nihilizm, cynizm, negacja transcendencji, synkretyczna papka New Age - lekarstwa, które mogą doprowadzić do zejścia samego pacjenta.

Jedną z ciekawszych propozycji „medycznych” Miłosza, który chciałby wyleczyć transcendencję z kartezjańskiego dualizmu (podziału na podmiot i przedmiot) jest rodzaj poetyckiego ekumenizmu. Po uważnym przeglądzie wątków, których ślady możemy odnaleźć prawie w każdym eseju i w wielu wierszach

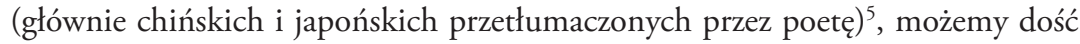
łatwo streścić tok jego rozumowania.

Zacznijmy od podstawowego przekonania poety, według którego powrót do poprzednich faz kultury jest niemożliwy; kiedy mówi o przyśpieszeniu historii, odkryciach naukowych, o globalizacji, zawsze pojawia się myśl o tej niemożliwości i zdanie „Nie oczekiwać, że wyobraźnia, kiedy raz zaczęła krążyć po swoich nowych orbitach, zdolna będzie się zatrzymać. $Z$ tego, co jest słabością, zrobić napęd siły — oto sposób” (Miłosz 1995: 25) można uznać za streszczenie wybranej strategii.

Skoro więc jesteśmy w fazie globalizacji — w planetarnej wiosce - z tego faktu należy zrobić napęd siły; wytworzyć inne układy globalizacji, inne niż uniformizacja w postaci miękkiej (papka New Age, subiektywizacja) czy twardej (neomanicheizm):

Co robił Staff, co robili inni tłumacze poezji chińskiej i japońskiej w dwudziestym wieku? Nic innego, jak dokonywali nieuniknionego połączenia Wschodu i Zachodu, nieuniknionego, bo dom nasz, planeta Ziemia, już przestaje być, na złe czy na dobre, podzielony na odgrodzone pola i zamknięte pokoje. Innym aspektem tego ruchu jest obecność religii wschodnich w Ameryce i w krajach Europy oraz ekumeniczne poszukiwania teologów chrześcijańskich [...] (Miłosz 1997: 383)

5 Patrz Przektady poetyckie: Poeci chińscy, s. 191-219 i Zen codzienny, s. 375-439. 
Należy odnaleźć czy raczej wypracować taki układ akulturacji, w którym oddzielne systemy (tutaj bardzo szerokie: Wschód/Zachód) nie będą się wzajemnie osłabiać, lecz wzmacniać. Miłosz wybiera ten fragment styku, na którym główna słabość Zachodu, czyli, według niego, kartezjański dualizm, może zostać wzmocniony czy uzupełniony przez myśl - poezję, religię (tutaj rozróżnienie prawie zanika) - Wschodu. Miłoszowi nie chodzi, co bardzo mocno podkreśla, o buddyzację chrześcijaństwa, ale o wzmocnienie najsłabszej jego strony, którą odkrywa w subiektywizacji i która doprowadza do osłabienia rzeczywistości. Ruch na osi Zachód/Wschód w refleksji Miłosza nie jest jednokierunkowy, ale dwukierunkowy, to rodzaj podróży — tam i z powrotem:

Przykład poezji Dalekiego Wschodu zachęcił mnie do szukania podobnych zalet, jakie w niej znalazłem i gdzie indziej. Tak jak po zwiedzeniu sal malarstwa odległych krajów wracamy do sal malarstwa rodzimego i widzimy je inaczej, tak poezja Europy i Ameryki ukazała mi pewien szczególny nurt, na który nie zwracałem dotychczas szczególnej uwagi. Zacząłem wybierać wiersze w różnych językach, które podobały mi się przez to, że honorują przedmiot, nie podmiot. (Miłosz 1997: 100)

Tę swoją kulturalną podróż tam i z powrotem, Miłosz streszcza mocno, melancholijnie i zabawnie jednym zdaniem: „Całe życie badał, podpatrywał sekrety wielkich mistrzów malarstwa, po to tylko, żeby namalować strumień koło swojej rodzinnej wioski i dwie gęsi na brzegu”. (Miłosz 1997: 8)

A oto właściwy tok rozumowania o dualizmie, który Miłosz podaje nam w jednym ciągu; jako streszczenie:

Powoływałem się kilka razy na buddyjskiego filozofa ze szkoły Kyoto, Keiji Nishitaniego, który napisał wielkie dzieło Religia i Nicość. Otóż wysuwa on tezę, że filozofia zachodnia zajmowała się stosunkiem podmiotu do przedmiotu w ten sposób, że celem podmiotu było poznać przedmiot, czyli rzeczywistość i opanować ją, podporządkować sobie. [...]. Według Nishitaniego, ten długi proces, ta ewolucja doprowadziła filozofię do samozaprzeczenia, do nihilizmu, gdyż „Ja”, podmiot w swoim zmaganiu, w swojej konfrontacji z przedmiotem doszedł najpierw do zanegowania przedmiotu, na którego miejscu stanęło tylko „Ja” (czyli do skrajnego subiektywizmu); z kolei owo "Ja" i jego rzeczywistość same zostały zanegowane. Najpierw więc nastąpiła utrata podstawy wszelkiej rzeczywistości czyli Boga — więc nastąpiło to, co nazwano „śmiercią Boga” (u Nietzschego), a potem doszło do „śmierci człowieka”. U Nishitaniego, lekarstwem na nihilizm jest — paradoksalnie — buddyzm, ponieważ w buddyzmie nie ma przeciwstawienia podmiot-przedmiot, podstawą, tłem, zarówno dla jednego jak i drugiego jest Pustka, Nicość — Sunjata ${ }^{6}$. Paradoksalnie, w ten sposób podmiot

${ }^{6}$ Pustka czy nicość w buddyzmie, jak Miłosz podkreśla, nie może być rozumiana w sensie nihilistycznym czy ontologicznym — jest to także Pełnia, rodzaj zbiornika energii, która zasila czy wypełnia jednocześnie podmiot i przedmiot (MP, 237). 
i przedmiot umieszczone są w innym stosunku — raczej utożsamienia niż zderzenia. (Miłosz 1995: 237)

Te rzeczy są dzisiaj znane i nie chodzi nam o ich przypominanie. Znany jest również wkład Miłosza w ich popularyzację: tłumaczenia haiku, skomponowanie książki Wypisy z ksiag użytecznych, w której jak stwierdza sam autor, udało mu się wyrazić swoje "instynktowne przywiązanie do świata widzialnego, dotykalnego, sensualnego” (Miłosz 1995: 247), jego własne wiersze „buddyjskie”, w tym najważniejsze: O zbawieniu (Miłosz 2011: 1353) i To jedno (Miłosz 2011: 914) gdzie odnajdujemy tę samą obronę rzeczywistości przed wszystkożernym podmiotem Kartezjusza. Kluczem do interpretacji pierwszego poematu byłaby pierwsza połowa buddyjskiego koanu: „jest poznanie, ale nie ma poznającego”, kluczem do drugiego - druga połowa: ,jest widzenie, ale nie ma widzącego”.

Znane jest również przekonanie Miłosza, że „katolicyzm może dużo zyskać na spotkaniu z buddyzmem" (Miłosz 1995: 241) i jego próby zakreślenia pewnego wspólnego zbioru dla dwóch religii, które, sprzymierzone, mogłyby wytoczyć na wspólnym terenie bitwę o transcendencję i rzeczywistość przeciwko subiektywnej nihilizacji:

Buddyzm wprowadza wymiar kosmiczny i tu spotyka się z katolicyzmem. Wymiar kosmiczny, bo mamy w buddyzmie ten ogromny wymiar czasu i to ustawiczne rodzenie się i umieranie - to jest jakiś wielki, olbrzymi wymiar. Tak samo jest w katolicyzmie: świętych obcowanie i śmierć Chrystusa pojęta nie tylko jako wydarzenie historyczne ale i kosmiczne; to również ten wymiar, nad którym ludzie niedostatecznie myślą. (Miłosz 1995: 251)

Te przekonania Miłosz dzieli z wieloma innymi badaczami współczesności: Tomaszem Mertonem i Józefem Tischnerem, żeby ograniczyć się do nazwisk najbardziej mu bliskich ${ }^{7}$.

Ciekawszą, bo może mniej znaną, sprawą byłaby próba rozwinięcia jego intuicji, które zaczęły się materializować znacznie później, a na które Miłosz, zgodnie z naszą metaforą wektorów rozwoju, jedynie wskazał palcem.

Kiedy Merton, Tischner, Nishitani, mówią o pożytku myśli buddyjskiej dla oczyszczenia i wzbogacenia chrześcijaństwa, myślą głównie w sposób jednokierunkowy: buddyzm jest tutaj ważny dla chrześcijaństwa. Jednak Miłosz sugeruje również coś w rodzaju sprzężenia zwrotnego — ruch dwukierunkowy. Istnieją dzisiaj teksty teologiczne i antropologiczne, które tę intuicję rozwijają ${ }^{8}$ Nie chodzi nam o wykazywanie zależności — wystarczy powiedzieć, że Miłosz,

\footnotetext{
Patrz Józef Tischner, Ksiądz na manowcach i Tomasz Merton, The Asian Journal.

8 Na przykład teksty R. Panikkar'a, T. Halika i inne.
} 
szukając ukrytych w ciemnym pokoju drzwi, natrafił ręką na przynajmniej jedno wyjście z globalnej i nihilizującej uniformizacji.

Rozwinięcie tego tematu przekracza tutaj nasze możliwości. Nie jest to oczywiście temat nieznany, przeciwnie, wielu badaczy pisało o intuicjach Miłosza i jego fascynacji buddyzmem 9 . Nie chodzi nam jednak tutaj o jego pogłębienie, chcielibyśmy raczej wskazać na zupełnie nowe ujęcia tego fenomenu w twórczości, która nie zajmuje się pisarstwem Czesława Miłosza. Wymienimy więc tylko dwa nazwiska współczesnych autorów całkowicie dwu-wyznaniowych, dla których buddyzm i chrześcijaństwo są jednakowo ważne i którzy wytyczają linie przecięć, pozwalające na obopólne wzbogacenie.

Ramon Panikkar, teolog uznany za jednego z ważniejszych we współczesnym świecie, w swoim teologicznym dziele L'expérience de Dieu rozwija temat przezwyciężenia zachodniego dualizmu, zajmując sie głównie tematyką katolickiej Trójcy - pogłębionej przez buddyjskie pojęcia advaity. Zajmuje się również kwestią przezwyciężenia pewnych tendencji w buddyzmie, które radykalizują pojęcie nicości, szukając pomocy w katolickiej koncepcji hipostaz: kto szuka?

Nie-dualistyczna wizja (advaita), w której boskość nie jest indywidualnie oddzielona od reszty rzeczywistości ani nie jest z nią całkowicie tożsama byłaby tutaj pomocna. Upaniszady np. zajmują stanowisko religijne, które nie opiera się ani na dialogu ani na monologu, ale na ponad-racjonalnym doświadczeniu „rzeczywistości”, która nas w pewien sposób „wchłania” w samą siebie. Jest to ta część mądrości, którą Azja może zaoferować zachodniej kulturze, tzn, upraszczając, nie-dualistyczna wizja rzeczywistości. I ta wizja może dopełnić obraz Trójcy. Z kolei relacyjność hipostaz wewnątrz Trójcy może uzupełnić obraz buddyzmu. Bóg nie jest ani Jednym (monizm), ani Innym (dualizm). Bóg jest biegunem rzeczywistości, jej biegunem twórczym; jest milczący, a więc niewyrażalny a jednak mówi w nas; jest transcendentny, ale immanentny w świecie; nieskończony a jednak ograniczony w rzeczach. Biegun jest niczym sam w sobie. Istnieje jedynie jako biegunowość — w relacji. Bóg jest relacją, intymną i wewnętrzną relacją ze wszytkim. (Panikkar 2014: 93)

Autor rozwija tutaj swoją koncepcję kosmotheoantropocentryzmu, która zdaje się dopełniać kosmiczne intuicje Miłosza.

Inny współczesny poeta, malarz i eseista, francuski akademik pochodzenia chińskiego — François Cheng, od lat opisuje swoją koncepcję piękna, w której splatają się chrześcijańskie i buddyjskie wątki — bardzo bliskie wizjom Miłosza.

9 Z najnowszych badań należy wymienić tu tekst Jerzego Jarzębskiego „N'être qu’un pur regard sans nom": Czestaw Mitosz et la souffrance du moi (w: Chauvin Danièle, red. 2013: 16 stron), Michała Masłowskiego Mitosz, Merton et le bouddhisme zen (w: Chauvin Danièle, red. 2013: 20 stron), książkę Agaty Stankowskiej Żeby nie widzieć oczu zapatrzonych w nic. O twórczości Czestawa Mitosza (Poznań 2013). 
Szczególnie rozważania Chenga o malarstwie - chińskim i europejskim wzbudzają u czytelnika Miłosza wrażenie déjà vu. Odnajdujemy tu ten sam ruch dwukierunkowy, podróż tam i z powrotem na terenie malartswa i poezji. Więcej — odnajdujemy tego samego malarza, który służy za łącznik dwóch tradycji - za ogniwo dorzucone w najsłabszym punkcie zachodniego łańcucha malarstwa (Cheng 2011: 47).

Miłosz często pisał o niebezpieczeństwie subiektywizacji także w malarstwie zachodnim, o impresjonizmie, który jest według niego „otwarciem jakiejś tamy subiektywizmu [...], coraz bardziej natrętnego opowiadania malarza o sobie; [...] malarstwo tylko jako to, co ja odczuwam, co ja tworzę, widzę...” (Miłosz 1995: 248). I odczytywał kubizm jako próbę oporu:

Niemniej zagadnienie cech stałych, niejako ukrytych w przedmiocie, było dla wielu niepokojące, na przykład dla kubistów, którzy analizując gitarę, jabłko czy ludzką twarz odkrywali, że składają się one z figur geometrycznych. (Miłosz 1997: 109)

Cézanne pojawia się w tym samym miejscu wywodu u Miłosza i u Chenga.

Cheng, podobnie jak Miłosz, zauważa, że klasyczne malarstwo zachodniej kultury odzwierciedla tę samą dualistyczną filozofię, która znalazła najpełniejszy wyraz w kartezjanizmie: stawia podmiot w pozycji uprzewilejowanej — ponad lub przed przedmiotem. Postać lub twarz znajdują się przeważnie na pierwszym planie — reszta służy za tło.

Miłosz napisał sporo wierszy malarskich i na temat malarstwa - prawie wszystkie wybrane obrazy mają jedną wspólną cechę — postać ludzka wychodzi z pierwszego planu i wtapia się — zmniejszona w tło albo znika zupełnie. Opisywał więc sceny z Corota, Turnera, malarstwa holenderskiego. Malarz, który wciąż powraca w jego poezji — ale w esejach jest wymieniony z nazwiska — to właśnie Cézanne, niekoniecznie jako kubista. Cézanne fascynuje Miłosza, ponieważ góra czy sosna, wciąż od nowa malowana w setkach odmian, wchłonęła - w sensie prawie dosłownym - malarza, który ją malował. Świat węwnętrzny Cézanne’a to góra Sainte-Victoire; a sam Cézanne zniknął, „wessany z siłą absolutną”, zostawiając po sobie hieroglificzny znak — podpis pośpiesznie rzucony w rogu obrazu (Miłosz 2011: 378).

Cézanne fascynuje również Cheng’a, ktory stawia podobne pytania, i, zastanawiając się nad zniknięciem Cézanne’a, pyta: a może jest na odwrót? Może to Cézanne wchłonął w siebie górę i to, co z niej zostało to obraz Cézanne’a - hieroglificzny znak jego życia wewnętrznego? Lub może obie wersje są prawdziwe? (Cheng 2011: 97). 
Refleksje Chenga są równie fascynujące, co mało znane, a ponieważ wydają się nam przedłużeniem refleksji Miłosza — przedłużonym wektorem wskazującym na wyjście z neomanicheizmu, pozwolę je sobie tutaj odtworzyć ${ }^{10}$.

Cézanne wciąż powracał do góry Sainte-Victoire, opowiada Cheng, stając przed nią w postawie przyjmującej i ofiarowującej zarazem. Wiedział, że musi otworzyć w sobie pustą przestrzeń, aby góra mogła w nią wejść, aby ta ogromna rzecz, przekraczająca go nieskończenie, mogła w nim zamieszkać. Czyli to, co nazywamy światem wewnętrznym, musiało najpierw stać się całkowicie puste, opróżnione z każdej rzeczy, którą nazywamy swoją, żeby przyjąć w siebie coś, co wchodzi weń z zewnątrz. W przestrzeń wewnętrzną malarza wchodziła potężna geologiczna siła, która od momentu wytrysku pierwszego ognia, wciąż, warstwa po warstwie, wspinała się nieprzerwanie wzwyż, w nieograniczoną przestrzeń powietrza, na spotkanie światła, odbijanego przez milion skrystalizowanych powierzchni granitowego bloku. $\mathrm{Z}$ powodu tej gry lustrzanych odbić, innych w każdej porze dnia i roku, tej bezustannej metamorfozy góry, Cézanne nie mógł się od niej oderwać i proces przyjmowania/ofiarowywania powtarzał się wciąż od nowa. Cézanne, oślepiony górą, zamienił się w oranta. Dobrze wiedząc jaka jest cena wpatrywania się w światło.

Malarz spalił się w oślepiającej kontemplacji.

Cézanne, ciężko chory, pustoszony przez nieustające migreny, wychodzi jak co dzień na spotkanie z górą Sainte Victoire. Wybucha burza. Cézanne traci przytomność i leży kilka godzin w gwałtownej ulewie. Umiera tego samego dnia. (Cheng 2011: 99)

Co po sobie zostawił? Swój świat wewnętrzny w postaci kilkunastu kwadratów płótna, na którym namalował hieroglif góry? Czy sam ten zewnętrzny pejzaż, który go zafascynowat: ogromny blok granitu?

I co chciał zrobić? - Mógłby spytać w tym momencie Miłosz — pochłonąć górę? Czy zniknąć? - tak, aby góra mogła stanąć na jego miejscu? Ruch jego pędzla był dośrodkowy? Czy odśrodkowy? Próbując odpowiedzieć na to pytanie, Miłosz czyta Nishitaniego, analizuje i tłumaczy poezję chińską i japońską. Pisze buddyjskie wiersze. Szuka wyjścia prowadzącego poza dualizm. I z Chin i Japonii wraca z powrotem do Europy, widząc już co innego w zachodniej kulturze.

Cheng, poeta i malarz, w swoim mieszkaniu tuż koło Louvre zwraca się do własnej, ojczystej kultury — do tradycyjnego malarstwa Chin.

Opowiada swoją pierwszą, sprzed ponad pół wieku, lekcję malarstwa u starego mistrza - przedstawiciela tradycji Song i Yuan (Cheng 1979: 65). Jaka jest

${ }^{10} \mathrm{~W}$ poniższym wywodzie dokonuję kompilacji kilku dzieł François Chenga, które wymieniam w bibliografii. 
autentyczna rzeczywistość człowieka na łonie żywego wszechświata, uchwycona w malarstwie Song i Yuan? Ich wizja, wyjaśnia stary mistrz, jest możliwa tylko wtedy, kiedy dusza człowieka wchodzi w rezonans z duszą uniwersalną, i dopiero ten stan rezonansu (shen-yun) jest najwyższym poziomem sztuki. Dusza uniwersalna nie jest naturą, ona jest poza naturą: to Tao — Droga, w której trwa Pustka pierwszego początku i pierwszy Oddech. Sama natura nie mówi nam niczego w sposób bezpośredni, gdyż to własnie my jesteśmy jej otwartym okiem i bijącym sercem.

$\mathrm{Na}$ chińskich obrazach często widzimy to samo: ogromny pejzaż góry, spadająca kaskada wody, naśladująca ją kaskada sosny, całość jakby wstrząsana nieustannym dreszczem, poruszana niewidocznym rytmem oddechu. W sercu pejzażu - mała postać człowieka - prawie całkowicie zagubionego w ogromie przestrzeni, zanurzonego we mgle Wielkiej Całości - człowieka, który widzi. Jeśli cierpliwie będziemy wpatrywać się w ten obraz, my również ujrzymy lub poczujemy, że postać ludzka znajduje się naprawdę w uprzywilejowanym miejscu widzenia, i że możemy się z nią utożsamić — razem z nią cieszyć się widokiem. Zobaczymy, że właśnie ta postać jest okiem i sercem olbrzymiego ciała. Jest jakby osią, wokół której rozpościera się organiczna przestrzeń, która powoli staje się przestrzenią wewnętrzną — człowieka, który widzi. Człowiek nie jest już osobnym, wykorzenionym bytem, który patrzy na wszechświat z zewnątrz. Jeżeli potrafimy widzieć świat — świat widzi nas. Nasza rzeczywistość, byt, życie, przeznaczenie - jakkolwiek to nazwiemy — jest częścią większej, kosmicznej rzeczywistości. I fakt ten nie tyle nas pomniejsza, co nas powiększa : nasza rzeczywistość zostaje postawiona w perspektywie otwarcia.

I Cheng wymawia słowo przezwyciężające dualizm: advaita.

W swoich rozważaniach na temat niewystarczalności dualistycznej postawy kartezjanizmu, w swoich wierszach, Miłosz szuka tej właśnie otwartej perspektywy, dzięki której wiersz staje się „czystym widzeniem bez nazwy”... Szuka momentu, w którym „ja” podmiotu zanika, wewnętrzna przestrzeń wchodzi $\mathrm{w}$ przestrzeń z zewnątrz i wiersz zamienia się w oko świata.

\section{To jedno}

Dolina i nad nią lasy w barwach jesieni.

Wędrowiec przybywa, mapa go tutaj wiodła,

A może pamięć. Raz, dawno, w słońcu,

Kiedy spadł pierwszy śnieg, jadąc tędy

Doznał radości, mocnej, bez przyczyny,

Radości oczu. Wszystko było rytmem

Przesuwających się drzew, ptaka w locie, 
Pociągu na wiadukcie, świętem ruchu.

Wraca po latach, niczego nie żąda.

Chce jednej tylko, drogocennej rzeczy:

Być samym czystym patrzeniem bez nazwy,

Bez oczekiwań, lęków i nadziei,

Na granicy, gdzie kończy się ja i nie-ja.

\section{BIBLIOGRAFIA}

Bauman Zygmunt. 2000. Globalizacja. Przeł. Ewa Klekot. Warszawa: Państwowy Instytut Wydawniczy.

Chauvin Danièle, red. 2013. Czestaw Mitosz, dialogue des cultures. Paris: Presses Universitaires Paris-Sorbonne.

Cheng François. 1979. Vide et Plein. Le langage pictural chinois. Éditions du Seuil.

Cheng François. 2006. Cinq méditations sur la beauté. Paris: Albin Michel.

Cheng François. 2011. Eil ouvert et cour battant. Paris: Desclée de Brouver.

Cheng François. 2013. Cinq méditations sur la mort. Paris: Albin Michel.

Cheng François. 2016. De l'âme. Paris: Albin Michel.

Merton Thomas. 1973. The Asian Journal of Thomas Merton. New York: New Directions Publishing.

Miłosz Czesław. 1995. Metafizyczna pauza. Kraków: Znak.

Miłosz Czesław. 1997. Piesek przydrożny. Kraków: Znak.

Miłosz Czesław. 1997. Żcie na wyspach. Kraków: Znak.

Miłosz Czesław. 2002. Druga przestrzeń. Kraków: Znak.

Miłosz Czesław. 2005. Przekłady poetyckie. Kraków: Znak.

Miłosz Czesław. 2011. Wiersze wszystkie. Kraków: Znak.

Panikkar Raimon. 2014. L'expérience de Dieu. Paris: Albin Michel.

Stankowska Agata. 2013. „Żeby nie widzieć oczu zapatrzonych w nic”. O twórczości Czestawa Mitosza. Poznań: Wydawnictwo Naukowe Uniwersytetu im. Adama Mickiewicza.

Scheler Max. 1993. Problèmes de sociologie de la connaissance. Paris: PUF.

Sosnowski Jerzy. 2015. Co Bóg zrobit szympansom? Warszawa: Wielka Litera.

Tischner Józef. 1999. Ksiądz na manowcach. Kraków: Znak. 
Magdalena Lubelska-Renouf

\title{
ACCULTURATION? OR ANOTHER VECTOR OF MODERNITY? REFLECTIONS ON THE THOUGHTS OF CZESŁAW MIŁOSZ
}

\author{
(summary)
}

While Max Scheler's acculturation problematic is once more topical, under the better known term "globalisation" (in the sense of westernisation), there are vectors in our culture that appear to run counter to this unifying trend. In our article, we examine one of Czesław Miłosz's poetic intuitions that is today "embodied" in the writings of François Cheng, the Chinese-born French poet and thinker. In his essays on beauty, we analyse the swinging back and forth between poetry, thought and painting; we also examine the meeting of Eastern (Buddhist and Taoist) and Western (Christian) thought; a meeting that Cheng and Miłosz particularly perceived in the pantings of Cézanne and which, while constituting a link between these two traditions, would, according to them, also make up for the greatest western weakness, i.e. Cartesianism.

\section{KEYWORDS}

Miłosz Czesław; Cheng François; Scheler Max; Cézanne; Acculturation; Chinese painting; Polish poetry; haïku 